\title{
BRINGING OLD MAPPING OF SABLE ISLAND INTO A MODERN GEOGRAPHIC REFERENCE FRAME
}

\author{
DAVID H. GRAY ${ }^{1}$ \\ Definitive Hydrographic \& Geodetic Consulting \\ Ottawa, Ontario, Canada
}

\begin{abstract}
Six independent surveys over the past 250 years have located Sable Island $\left(44^{\circ} \mathrm{N}, 60^{\circ} \mathrm{W}\right)$ in different locations. This paper correlates the surveys based on the limited number of common points and comments on the surveying methods that were employed and concludes that the various positions are more due to the quality of surveying than to the shifting of the island or to tectonic plate motion. The implications, in terms of hydrographic charting and legal basis of sovereignty of maritime areas and of the National Park Reserve, are also discussed.
\end{abstract}

Key Words: Sable Island, surveys, mapping, charting

\section{PEDIGREE}

This paper is a rewritten, updated and corrected version of a paper entitled "Where has Sable Island been for the past 200 Years" published in International Hydrographic Review; Vol. 69 (2):1992 and CISM Journal ACSGC; Vol. 46 (3):1992. Readers are directed to either of the original papers if they wish a fuller explanation of the survey aspects.

\section{INTRODUCTION}

To appreciate the extent to which Sable Island has moved, or stayed stable, over the past 250 years, one needs to bring the mapping of the island into a common geographic reference frame. The research for this paper was done in the 1990s, was published, albeit in small press-run professional magazines, but needs to reach a wider audience who are concerned about the long-term effects of erosion and accretion at Sable Island. 


\section{GEOGRAPHIC BACKGROUND}

Sable Island is a crescent-shaped island of two parallel sand dunes $32 \mathrm{~km}$ long by $1.6 \mathrm{~km}$ wide that is situated $145 \mathrm{~km}$ off the Nova Scotia coast, at $44^{\circ} \mathrm{N}$ latitude and $60^{\circ} \mathrm{W}$ longitude, almost at the edge of the continental shelf. According to the surveys and the relocations of the west lighthouse over the years, the island was longer and the line of dunes farther apart so that there used to be a tidal lagoon between them. The island is exposed to the erosive action of prevailing westerly winds and the Gulf Stream which flows eastward along both sides of the island. The last vestiges of the cold Labrador Current flow westward some distance north of the island creating fog banks when warm moist air meets its cold water. Sable Island's sand dunes rise to a maximum height of 25 meters and support only stabilizing grasses. Thus, this low-profile island, its east and west sand banks, the fog and the ocean currents are navigational hazards to ships on transatlantic routes and to American Grand Banks fishermen.

In the early $1800 \mathrm{~s}$, debates raged as to whether it was best to put lighthouse(s) on the island - thus tempting mariners towards the island to confirm their position - or whether to leave the island unlit - thereby encouraging mariners to keep well clear. In part, the debate was influenced by the capabilities of the light sources and optics of the day, which were far inferior to present day equipment. Lighthouses were not built until 1873, but lifesaving stations were built and manned in 1801 .

Mariners can only stay clear of a hazard if they know where they are and where the hazard is. Thus, for the past 250 years hydrographers and surveyors have tried to position the island as accurately as possible to fulfill the second requirement. With respect to surveying, the island is also an anomaly. It is an isolated feature, not part of a continental coast or coastal islands where survey work can be part of the continental geodetic network. Instead, the island had to be astronomically positioned until after World War II when various airborne distance measuring techniques were developed, or until the 1970s when satellite positioning techniques became available. Survey work on the island has been frustrated by the fact that it is remote, there is no harbor, there are no permanent natural features and few permanent man-made features, and the shape and topography are not conducive to good survey quality. 
Sable Island East Light is the key to the determination of the absolute location of the island over the years. It was built in 1873 as an octagonal wood tower. It was destroyed (perhaps just inoperable) in 1934 and replaced in 1935 "immediately westward of site of former light" (Notices to Mariners \#217 of 1934 and \#197 of 1935, commonly abbreviated to $217 / 34 \& 197 / 35$ ). The structure was moved further west in 1974 (i.e., Canadian Coast Guard construction date) and advertised in Notices to Mariners on 31 December 1976 as a new light (Notices to Mariners, List of Lights correction, 31 Dec. 1976). The Maritime Museum of the Atlantic, Halifax, has a photograph of the wood tower and steel tower side by side (See Fig 1). There is a good survey connection between the pre- and post-1974 lights on the same geodetic datum to quantify that movement at 145.4 meters (477 ft) on an azimuth of $265^{\circ} 33^{\prime}$. (Nautical Geodesy Section, CHS, survey records) Both reconstructions were in close proximity such that the same house was used as the lighthouse keeper's residence. The light became unwatched in 1960 and discontinued operation in 2012, although the structure remains. The author has searched through all the List of Lights, Buoys and Fog Signals and Notices to Mariners as far back as 1912 and finds no indication of other reconstructions.

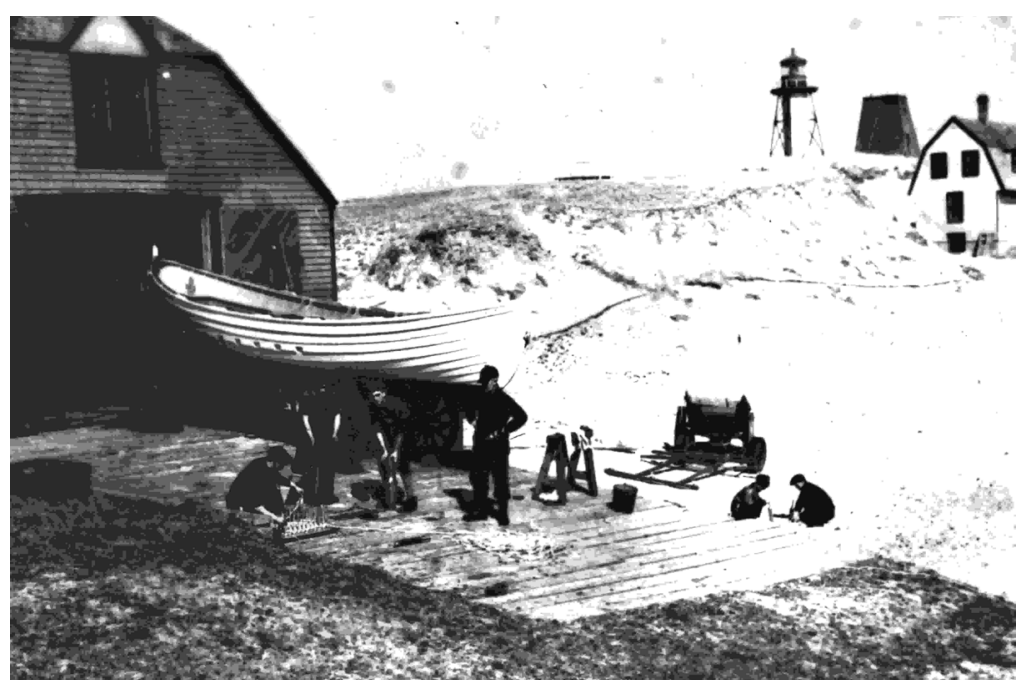

Fig 1 Sable Island Life Boat Station circa 1934 or 1935 showing the original octagonal, sloping sided, East End Light as well as its steel skeleton replacement. [Maritime Museum of the Atlantic photo MP221.49]. 
On the other hand, West Light was built in 1873, moved in 1883, $1888,1917,1940$ (to near the flagstaff at the Main Lifesaving Station whose astronomic coordinates were determined in 1851 and 1899, lighthouse positioned astronomically in 1947), 1951 (proposed site connected by survey to 1940 lighthouse), and 1971. Each time the move was eastward from one to three kilometers, except the last which was southeast by only 40 meters. In 2004, the light discontinued operating, although the structure remains with aircraft warning lights on the structure.

\section{SURVEY WORK}

\section{6-67}

The 1766-7 map of Joseph DesBarres placed the island wholly north of $44^{\circ} \mathrm{N}$ and west of $60^{\circ} \mathrm{W}$ (DesBarres 1777).

\section{8}

The 1828 survey by Capt. Jones of HMS Hussar was compared by Capt. H.W. Bayfield in his 1851 survey as having the same east end, same central part, but there was $3 \mathrm{~km}$ of erosion at the west end between the two surveys (McKenzie 1984, p. 1xxi; McKenzie 1986, p. 387). The author has not personally seen the 1828 survey plan.

\section{1}

In his 1851 survey (British Admiralty Rough Sheet D9148, 1851), Bayfield's latitude determination seems correct and the longitude difference between three locations on Sable Island and astronomic piers in Halifax and Quebec City also seems correct, but the quoted longitude on 1853 edition of British Admiralty (BA) chart 2171 is different from the present-day longitude by almost three minutes of arc because of the updating of longitudes in Canada circa 1855. The 1851 survey was done to resolve the discrepancies in the location of the island - one of the suspected reasons for so many shipwrecks.

\section{2}

The British Admiralty also apparently performed some survey work dated 1862, but from the editions of chart 2171 between 1853 and 1904 that are held at the Public Archives of Canada, it appears that the 1862 survey was only offshore soundings. 


\section{9}

The chief engineer, Dept. Marine and Fisheries, Wm.P. Anderson, $\mathrm{CE}$, surveyed the island in 1899 and the results were first published on the 1904 edition of BA chart 2171. The Main (Lifeboat) Station was positioned astronomically and that position agrees with later determinations. The rest of the island was surveyed by ground surveys which have a $15 \%$ (approx) scale error since the charted position of East Light is in error by 2.4 nautical miles $(4.4 \mathrm{~km})$ on a radial line from the Main Station. The scale error may be more or less constant over the island, since the positions of the houses near No. 3 Station agree favorably with their positions in the 1851, 1947 and 1963 surveys once the scale error has been removed. The 1941 edition of BA chart 1651 uses this 1899 survey of the island.

\section{7}

The next survey was in 1947 by W.H. Stilwell (Stilwell 1947), Geodetic Survey of Canada. He positioned the East and West Lights astronomically and traversed (measuring angles and distances) between them as a check. (Geodetic Survey Division, NRCan, survey records) The misclosure of 51.2 meters (168 feet) was attributed to the accuracies of the astronomic observations $( \pm 100 \mathrm{ft}( \pm 30 \mathrm{~m})$ in latitude and $\pm 550 \mathrm{ft}( \pm 166 \mathrm{~m})$ longitude at each site) and to changes in the direction of the vertical. The gravitational field of the Earth varies with location creating a "nubbly pear" shape for Mean Sea Level whereas the surveyors calculate positions on the Earth's surface using an ellipsoid (an ellipse revolved around the spin axis) to represent Mean Sea Level. The angle between the local gravitational vertical (often determined astronomically) and the vertical to the ellipsoid is known as the deflection of the vertical. He also positioned, by traverse and triangulation, the proposed site of the West Light that was finally commissioned in 1951. Hydrographic and Map Service of Canada plan S-117 at a scale of 1:63,360 (1 inch $=1$ statute mile) of the island was published in 1947 and it incorporates Stilwell's observations. This rendition of the island is shown in the 1962 edition of BA chart 1651 and in the 1952 New Chart, CHS 4490. It is CHS 4490 that is used as a reference chart in the Territorial Sea Geographical Coordinates Order (Consolidated Regulations of Canada (CRC) 1978, c. 1550). 


\section{2-9}

Prof. H.L. Cameron did some research into the stability of Sable Island in the early 1960s and published The Shifting Sands of Sable Island in which he provides additional coastlines of Sable Island in 1952, 1955 and 1959 (Cameron, 1965). His original compilation of map comparisons is held at the Public Archives of Nova Scotia, Map Division. The three coastlines add nothing to the absolute position of the island. Prof. Cameron compared the various epochs by keeping the east end of Lake Wallace (the once large interior lagoon) at a constant location, which was an erroneous assumption, and did not recognize the scale problem in the 1899 survey. Therefore, his results show that the island wandered more widely than, in fact, was the case.

\section{Modern surveys}

The 1963 Aerodist survey, 1976 Doppler satellite survey, 1984 Laplace azimuth and Doppler satellite surveys and 1991 differential GPS positioning just strengthen the geodetic precision. (Geodetic Survey Division, NRCan, survey records, and Craymer, 2015)

\section{ANALYSIS OF MAPS AND CHARTS}

Fig 2 shows the effect of accepting the maps and charts at face value. Although it is normal to think of events in chronological order, it is necessary to use the reverse chronological order to bring all the old surveys up to the present day, by relating common features to where they are now known to be located.

\section{NAD83 estimates the tectonic plate movement}

It is now generally recognized that the surface of the Earth is made up of tectonic plates (usually the size of continents) that slowly move, either separating from each other or crashing into each other where one plate ends up going under another. Global navigation satellite systems, such as GPS, are now so accurate that millimeter precision is possible relative to the Earth's centre of gravity, and the velocity of the station marker over the recent past can be determined. Station 'Red' on Sable Island is one such point where these surveys have been carried out. 


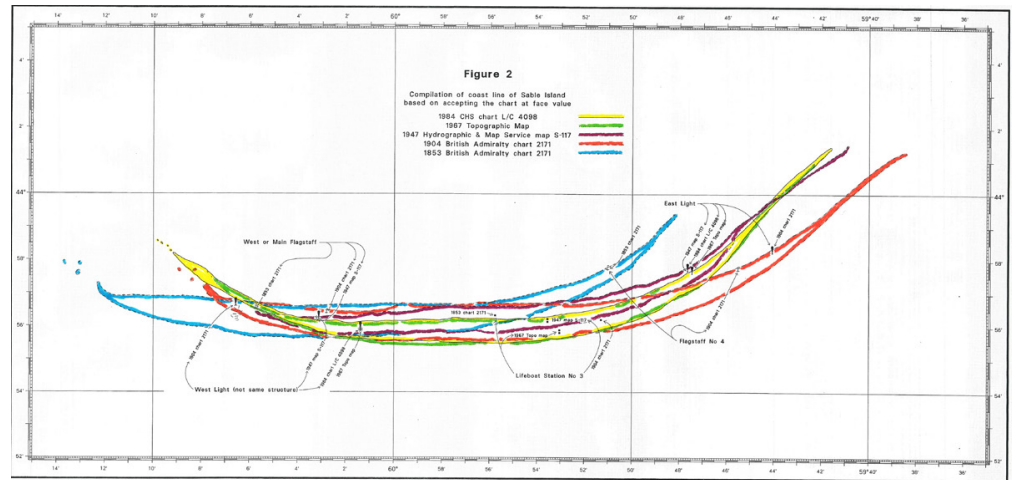

Fig 2 Compilation of coastline of Sable Island based on accepting the charts at face value: 1984 CHS chart L/C 4098,1967 Topographic Map, 1947 Hydrographic \& Map Service map S-117, 1904 British Admiralty chart 2171, \& 1853 British Admiralty chart 2171. (Also see Appendix A).

Velocity components are estimated to be:

$+9.93 \mathrm{~mm} /$ year in latitude

$-14.80 \mathrm{~mm} /$ year in longitude (Craymer 2015)

These velocities can be considered estimates of tectonic plate velocities in the vicinity of Sable Island, not the velocity of the station marker moving on the island. Over a 250 year period (say 1765 to 2015), the total horizontal shift would be 2.5 meters northward, 3.7 meters eastward, if these velocities were constant. Halifax exhibits the similar tectonic movement.

\section{NAD83 versus NAD27}

Since geodetic coordinates have to be related to a specific datum, the geodetic coordinates listed in this paper are related to North American Datum of 1927 (NAD27), since a full set of NAD83 coordinate values was not available when the surveys were being analyzed in 1991 and since all charts and maps referred to in this research, which are related to a geodetic datum, use NAD27 coordinate values. Since the research was done, the geographic grid on the 2001 edition of CHS chart 4098 was shifted to NAD83, but the chart is still based on the pre-1984 surveys and the topographic map was published on NAD83 in 2003 (most of the data current as of 1996), and again published in 2013. 
The difference between the two geodetic datums can be demonstrated by comparing the NAD83 and NAD27 coordinates of 'Red'. Essentially, 'Red' can be considered the origin of the coordinate system for the island, because it is the survey point that was positioned by Doppler satellite and GPS techniques.

NAD83 (1997)

NAD27 (1985)

Difference

$$
\begin{aligned}
& 43^{\circ} 57^{\prime} 42.792^{\prime \prime N}, 59^{\circ} 47^{\prime} 11.341^{\prime \prime} \mathrm{W} \\
& 43^{\circ} 57^{\prime} \frac{42.551^{\prime \prime} \mathrm{N}, 59^{\circ} 47^{\prime}}{0.241^{\prime \prime}} \frac{14.088^{\prime \prime} \mathrm{W}}{-2.747^{\prime \prime}(61.69 \mathrm{~m})}
\end{aligned}
$$

\section{CHS Chart L/C 4098}

The 1984 CHS chart L/C 4098 was the most recently published map or chart of the island available in 1991 (the time of the analysis) and was used as a basis to compare all the other maps and charts. (The "L/C" prefix indicates that the 1984 edition of the chart had hyperbolic lattices; these were added for positioning by the Loran-C time differences.). A composite map showing the movement of the island (or lack of it) is given as Fig 3.

The NAD27 positions of survey points on the island were computed in 1983 and are an amalgamation of surveys since 1963. The 1985 revised NAD27 position (Nautical Geodesy Section, CHS, survey records) of Station 'Vern' is insignificantly different from the 1983 position listed in the Title Block of the 1984 edition:

1985 adjusted position 1983 adjusted position

Difference

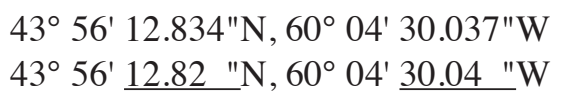

(Title Block)

$-0.003^{\prime \prime}$

$(0.4 \mathrm{~m})$

\section{Topographic Map}

The 1967 First Edition of the 1:50,000 National Topographic map of Sable Island was based on air-photos and field surveys done in 1963. Aerodist lengths from four first-order triangulation points in Nova Scotia provided absolute positioning of a survey point on the island to an accuracy of \pm 10 meters. The position of the East Light (1934-74) has since been modified: 


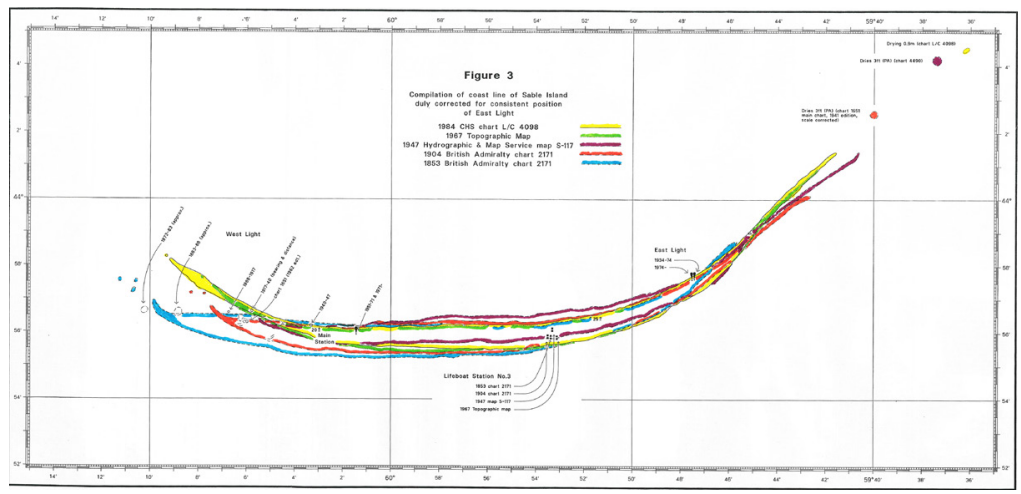

Fig 3 Compilation of coastline of Sable Island duly corrected for consistent position of East Light: 1984 CHS chart L/C 4098, 1967 Topographic Map, 1947 Hydrographic \& Map Service map S-117, 1904 British Admiralty chart 2171, \& 1853 British Admiralty chart 2171. (Also see Appendix B).

1985 adjusted position

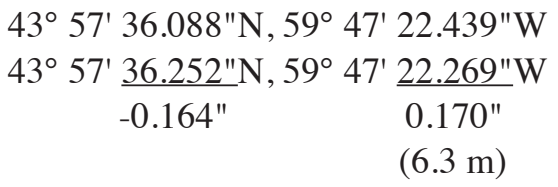

\section{Map S-117}

The 1947 survey by W.H. Stilwell, Geodetic Survey of Canada, published as map S-117 by the Hydrographic and Map Service of Canada, is based on the astronomic positions of the East (1934-74) and West (1940-7) Lights (Stilwell 1947). The astronomic positioning was done by the equal altitude method; i.e., observing stars as they crossed a specified (usually $60^{\circ}$ ) angle of elevation. This method is usually accurate to a second of latitude and about 7.5 seconds of longitude (i.e., 0.5 seconds of time). The position of East Light (1934-74) has since been improved:

1985 adjusted position

1947 astro. position

Difference

$$
\begin{aligned}
& 43^{\circ} 57^{\prime} 36.088^{\prime \prime} \mathrm{N}, 59^{\circ} 47^{\prime} 22.439 " \mathrm{~W}
\end{aligned}
$$

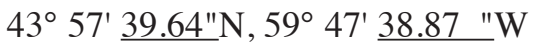

$$
\begin{aligned}
& -3.552 \\
& -16.431 " \\
& \text { (382.4 m) }
\end{aligned}
$$

The difference in position is caused, to a large extent, by the astronomic to geodetic differences as demonstrated by the comparison between astronomic and geodetic coordinates at the 1984 Laplace Station ('Red'): 
1985 adjusted position 1984 astronomic position Difference

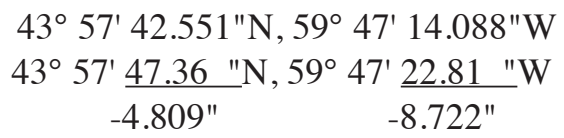

The differences between the 1947 and 1984 astro-geodetic differences are totally within the expected accuracies of measuring latitude and longitude for exploratory positioning and Laplace azimuth purposes.

\section{Survey}

In 1899, Wm.P. Anderson, CE, Dept. Marine and Fisheries, only positioned the Main Flagstaff (near the 1940-47 West Light) (British Admiralty Fairsheet B8922, 1899) . He observed either: 1) the sun at local noon for latitude and the sun in the morning and afternoon as it crossed various angles of elevation for longitude (Bayfield's method in 1851 (Admiralty Manual of Hydrographic Surveying, Vol. $1,1965)$ ); or, 2) the stars as they crossed his local meridian noting either the elevation angle to determine latitude or the time to determine longitude. (Brookes, 1991) Position accuracy by either method is typically several tens of seconds of latitude and longitude, particularly longitude because Anderson's time would have to have been brought by chronometer from Halifax (Stilwell had the advantage of short-wave radio time signals.) The comparison between his position of the flagstaff and Stilwell's position of the 1940-7 West Light are sufficiently good as to indicate no major positioning problems.

1947 astro. position 1899 astro. position Difference

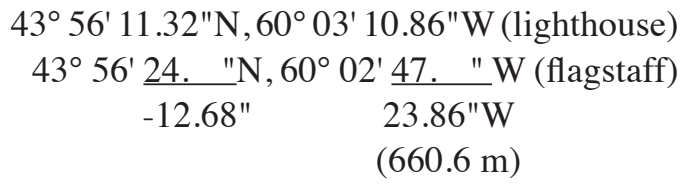

When the 1899 survey (i.e., Fairsheet B8922, the 1904 edition of chart 2171 or the 1941 edition of chart 1651) is brought to the scale of chart $4098(1: 100,000)$ and the flagstaff is positioned on the ap-

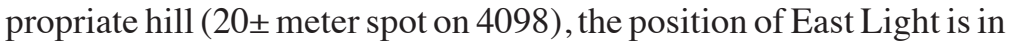
error by 2.4 nautical miles $(4.4 \mathrm{~km})$ on a radial line from the flagstaff. This is the first indication of a major scale error in Anderson's work. The error appears to be in the overall scale which probably finds its source in the one length that was measured to control the scale of his terrestrial triangulation survey. When the chart is reduced to the 
correct distance between the flagstaff and East Light (knowing that the 1873-1934 East Light is only slightly east of the 1934-74 position), then the position of the houses at No. 3 Lifeboat Station fall within a reasonable distance $(1 / 4$ mile or $0.5 \mathrm{~km})$ of their positions on the 1853, 1947 and 1967 maps. The chart shows the No. 4 Flagstaff that is used in locating the 1851 survey.

\section{Survey}

Capt. H.W. Bayfield surveyed the island and surrounding waters in 1851 near the end of an illustrious career as a hydrographer. He regularly endured great hardships and took painstaking care to get his surveys correct. And indeed they were! According to his journal, he observed the astronomic position (see above for method) at the east and west ends of the island and at the Main Station. He brought 13 chronometers with him and calibrated them at Arichat Island before and after the trip to Sable Island. According to BA chart 2171 (1853 edition) the East Point has a position of $43^{\circ} 59^{\prime} 05^{\prime \prime} \mathrm{N}, 59^{\circ} 48^{\prime} 27^{\prime \prime} \mathrm{W}$, but the Fairsheet L7820 describes the longitude relative to Dockyard Tablet, Halifax and Observation Bastion, Quebec City. Therefore, Bayfield's values for the longitude of these two points are:

Dockyard Tablet, Halifax

Observation Bastion, Quebec City

$$
\begin{aligned}
& 63^{\circ} 37^{\prime} 47.4^{\prime \prime} \mathrm{W} \\
& 71^{\circ} 16^{\prime} 00.4^{\prime \prime} \mathrm{W}
\end{aligned}
$$

On the 1829 BA chart 319 of Quebec City (surveyed by Bayfield in 1827), the position of the Observation Bastion is quoted and this position can be compared to its transferred position onto the 1990 edition of CHS chart 1316 of the Port of Quebec:

1990 CHS chart 1316

1829 BA chart 319

Difference

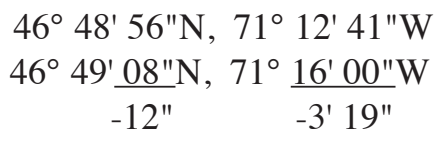

$(4235 \mathrm{~m})$

Secondly, the 1854 original printing of BA chart 2320 of Halifax Harbour, which was surveyed by Bayfield in 1853, and also the 1869 reprint of the same chart show the location of the astronomic pier in the Halifax Naval Dockyard. When this position is transferred to the modern chart of Halifax Harbour (CHS chart 4202) by its relationship to nearby cultural features, the positions are: 
1990 CHS chart 4202

1869 Reprint of BA chart 2320

1854 BA chart 2320

Derived from BA chart 2171

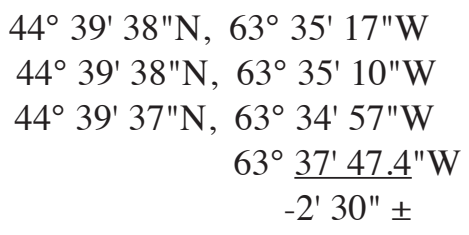

(3300 m)

Thirdly, the position of West Flagstaff, which later became Main Flagstaff, can be compared with the 1899 and 1947 positions:

1947 astro. position

(of 1940-47 West Lt)

1899 astro. position

1853 astro. position

$$
\begin{aligned}
& 43^{\circ} 56^{\prime} 11.32 \text { "N, 60 } 03^{\prime} 10.86 \text { "W } \\
& 43^{\circ} 56^{\prime} 24 . \quad \mathrm{N}, 60^{\circ} 02^{\prime} 47 . \quad \mathrm{W} \\
& 43^{\circ} 56^{\prime} 33 . \quad \mathrm{N}, 60^{\circ} \underline{05^{\prime} 44.6} \text { "W } \\
& -3 \text { ' } 00 \text { " } \\
& \pm(4000 \mathrm{~m})
\end{aligned}
$$

Each of the 1853 West Flagstaff, Halifax (as derived from the 1853 BA chart 2171) and the 1829 Quebec City positions appear to be too large by about three minutes of longitude, confirming a systematic longitude error (relative to Greenwich) throughout Eastern Canada at this time.

In 1852, the longitude of Halifax was corrected to agree with the longitude of Harvard University through the exchange of telegraphic time signals. (Thomson 1978). Thus in 1853, at the time of the survey of Sable Island, Bayfield was in the midst of changing longitudes. He had the old version of longitudes, based on Quebec City, and the new version of longitudes based on Harvard and a major difference of 3 minutes of arc between them. This may explain why he quotes the two longitude differences on Fairsheet L7820. In 1855, the longitude of Quebec (the base station for longitudes in Canada at the time) was amended by about three minutes of arc following longitude difference determinations with Harvard University (Thomson 1978).

If one accepts Bayfield's position of the island at face value from the 1853 edition of chart 2171, then all information is too far west by $4.4 \mathrm{~km}$ (2.4 n.m.). Main Station and eastern (No. 4) flagstaff are capable of being used to locate the island, since it was 22 years before the construction of the first two lighthouses. 


\section{6-7 Survey}

There is no feature on DesBarres' chart to be able to relate it to subsequent maps and charts. However, it must be remembered that in 1766-7, longitude was practically impossible to determine since accurate time pieces were not yet capable of going to sea and lunar distance determination of longitude was inaccurate due to poor quality almanacs. Although DesBarres located the island totally north of $44^{\circ} \mathrm{N}$ and west of $60^{\circ} \mathrm{W}$, it is reasonable to assume that he surveyed within the survey standards of the time, given the quality of the equipment and procedures available to him.

\section{CONCLUSION}

The conclusion that can be drawn from all the maps and charts is that there have been a multitude of positions for Sable Island (see Fig 2), more due to the quality of the surveying than to the wholesale shifting of the island. These differences have been resolved in Fig 3. Tectonic plate movement is estimated to be less than 5 meters over the past 250 years and thus is not a factor. The accuracy of relating these old coastlines in the modern day geodetic reference system is still limited by the old surveying methods of positioning features. This is demonstrated by the various locations of Lifeboat Station No. 3 on Fig 3 which shows that positions are only accurate to about a quarter nautical mile (approx. 500 meters).

\section{HYDROGRAPHIC IMPLICATIONS}

The significance of the multitude of independent surveys of Sable Island that have only now been correlated shows that modern charts, particularly ones used in electronic charts, must recognize that old survey positions are not as accurate as those determined by modern survey methods.

The 1851 survey by Bayfield shows us that the origin of astronomic longitudes of old surveys must be considered since the base station for eastern Canada was updated in 1855 by three minutes of arc. There are still several CHS charts (and probably of other nations too) based on astronomic datums where the astronomic/geodetic differences are in the order of 30 arc seconds or more. 
The 1899 survey by Anderson shows us that all surveys where scale (length) was extended through independent triangulation networks can be susceptible to error.

The 1947 survey provides examples of astronomic to geodetic coordinate differences that are significant; e.g., 1/4 mile, given present day navigation equipment such as GPS.

\section{LEGAL IMPLICATIONS}

According to the 1958 Geneva Convention on the Territorial Sea and the 1982 Law of the Sea Convention, "the normal baseline of the territorial sea is the low water line along the coast as marked on large-scale charts officially recognized by the coastal state." [United Nations Convention on the Law of the Sea 1983, Article 5]. Presuming this method for determining the territorial sea limit was a legal presumption before being codified in 1958 and 1982, then the 1851 survey, as reflected on chart 2171, would have endured from the 1853 edition until the first edition of the same chart showing the 1899 survey, which may well have been the 1904 edition. The 1899 survey would have endured from then until the first navigational chart showing the 1947 survey, which might have been the 1952 edition of CHS chart 4490. The 1947 survey would have been accepted as the low water line from that time until the publication of CHS chart L/C 4098 in 1984.

Given Canada's history of being a British colony, or part of the British Empire or Commonwealth, it is not presumptuous to say that British Admiralty charts would have been officially recognized by Canada. Moreover, the British Admiralty was responsible for charting Canada's coastal waters up to at least 1904. Its last survey in Canada was in 1939. The copper plates for printing charts of Canadian coastal waters, which were still in force, were transferred to the Canadian Hydrographic Service just after World War 2, and some of those charts lasted into the 1990s. In the case of the 1899-1947 time frame, there would have been even fewer qualms for Canada to accept the British Admiralty chart of Sable Island since it was based on a survey by a senior officer of the Canadian government.

The topographic map published in 1967 and the 1947 special map, S-117, would not have been recognized as appropriate charts for the depiction of the low water line because they are not, in themselves, navigational charts although the latter was obviously used as the 
basis of the 1952 edition of CHS chart 4490 and the 1962 edition of BA chart 1651.

You may ask - So what? The legal implication came to the fore in the early 1990s when a possible litigation in Canada posed the question as to where the territorial sea limit was in 1941 with respect to other positions determined in the 1970s. The court action was dropped based, in part, on these technical findings. This paper is not the forum to discuss the pros and cons of the case, since there were other facets, but it is used to demonstrate that the exercise is not trivial.

\section{IMPLICATIONS FOR SABLE ISLAND NATIONAL PARK RESERVE}

There may be geographically referenced data on these historical maps and charts, either printed on them or added by persons unknown, for which Parks Canada wants to know their present-day positions. Positions of wrecks and of buildings are obvious data for archeologists. The research done in this paper should help them convert those old positions into something compatible with GPS.

The Sable Island National Park Reserve was defined in 2013 as being, "all of Sable Island located near the geographic coordinates of $43^{\circ} 56^{\prime}$ north latitude and $59^{\circ} 55^{\prime}$ west longitude including its shore and foreshore." (Canada National Parks Act, Schedule 2, S.C. 2000 , c. 32). There are probably two legal interpretations of the timing aspect of this definition. Is the Park Reserve defined as the island changes shape day to day (timing option \#1) or is the Park Reserve defined as of the date that the Act was amended to include this Park Reserve (timing option \#2)? Also, the Act states that the Park Reserve includes the foreshore of the island which means that it extends to the low water line of Sable Island, but presumably not to the detached low tide elevations (or drying shoals) that are near the island, particularly off the east end. Under Section 140.1 of the Canada-Nova Scotia Offshore Petroleum Resources Accord Implementation Act 1988 (S.C. 1988 c. 28), "no person shall carry on any work or activity related to the drilling for petroleum, including exploratory drilling for petroleum, in Sable Island National Park Reserve of Canada or within one nautical mile seaward of its low-water mark". To further limit the activity near the island, the Sable Island Regulations under the Canada Shipping Act 2001 (S.C. 2001, c. 26) 
states that "no person shall, without having first obtained written permission from the [District Marine] Agent [Dept. of Transport, Dartmouth], a) erect any building or structure on the Island or in the waters within one mile thereof; b) make any excavation or roadway or otherwise disturb the natural contours of the surface of the Island or of the bars or coasts thereof; c) use any explosive on the Island or in the waters within one mile thereof; or d) molest, interfere with, feed or otherwise have anything to do with the ponies on the Island." (Sable Island Regulations, Para. 5) (CRC, 1978, c. 1465). However, the Shipping Act and the Sable Island Regulations do not specify whether "mile" refers to a statute mile (1609.344 meters) or a nautical mile (1852 meters).

Canada Lands Surveyors are the professionals who would have to delineate (since it would be hard to demarcate) the limit of the Park Reserve. Besides the timing aspect mentioned above, they would face the problem of which low water line to use. In cadastral surveying, the desired low water line would be the Mean Low Water waterline. But nautical charts show the Lower Low Water Large Tides waterline and the topographic maps show the Mean Sea Level waterline.

Fig 2 illustrates where the island has been thought to be located by accepting the mapping at its face value. Fig 3 illustrates where the island has been surveyed over the past 160 years when brought to a common geodetic datum - in this case NAD27. (The NAD83 position of any feature on the island is 62 meters east of its NAD27 position.) Fig 3 shows that the central and eastern parts of the island are more stationary than the western part which has eroded and accreted such that it is shorter and has swung to the north. Thus, the island is always being reshaped, which is hardly surprising given that it is made of sand and is exposed to prevailing westerly winds and to the Gulf Stream.

Therefore, timing option \#1 interpretation of the definition of the Park Reserve is that its limit is always in a state of flux in the absolute positioning sense. How are petroleum exploration companies to know where the island will be in 10,20 or 50 years' time? Where will the outer limit of the buffer zone be when they want to explore or develop a petroleum deposit? What is the size of their exploratory lease, and hence the amount of royalties they are required to pay? What is needed is a definition of the National Park Reserve that is fixed in terms of geographic coordinates so that everyone knows 
where the limits are - for all time. Such a definition already exists in Canadian legislation in Schedule II of the Canada-Nova Scotia Offshore Petroleum Resources Accord Implementation Act (1988). An entity called "Limits of Sable Island" is defined as an eight-sided polygon, each corner of which is defined by geographic coordinates. The polygon contains the island and water areas around the island.

Timing option \#2 interpretation of the definition of the Park Reserve requires the low water line as of the date when the Park Reserve was created. CHS chart 4098 shows the Lower Low Water Large Tides waterline as of 1984 and the topographic map shows the Mean Sea Level waterline on the day that the aerial photography was taken. Neither shows the Mean Low Water waterline as of that particular day. There is about 0.3 meters vertically between Mean Low Water and Lower Low Water Large Tides and about 0.5 meters vertically between the Mean Low Water and Mean Sea Level. Horizontal displacement is a function of the slope of the beach.

Therefore, it is the author's opinion that there are legal and technical imprecisions in the present wording of the definition of the Sable Island National Park Reserve.

\section{SUMMARY}

The results of the analysis of the positioning of Sable Island show that the island has physically moved far less than has previously been thought, that there has been at least one major survey error committed, that most survey data are within the expected accuracy limits of the equipment and procedures used, that there are hydrographic charting repercussions to incorporating old surveys into new charting, that there are legal implications in terms of sovereignty that still persist even after the surveys have been superseded, and that there are legal and technical implications that affect the definition of the National Park Reserve.

Acknowledgements A research paper such as this one can not stand alone on the modern day evidence, but depends on the quiet, diligent, work of various archivists who are always pleasant in retrieving the material from their storage places. Patrick McIntyre of the Map Library of the Public Archives of Canada, Garry Shutlak of the Public Archives of Nova Scotia and Mary Blackford of the Maritime 
Museum of the Atlantic (Halifax) are such people. Brian Ballantyne, Surveyor General's office, pointed the author to the salient pieces of Canadian legislation concerning Sable Island. A special word of thanks goes to Rear Admiral J.A.L. Myres, RN, and the archive staff at the Hydrographic Department of the Royal Navy at Taunton who provided the Rough sheets and Fairsheets of the 1851 and 1899 surveys and copies of BA charts 1651 and 2171.

\section{REFERENCES}

Brookes, W.A. (1991). (Geodetic Survey, Energy Mines \& Resources (now NRCan), Ottawa. , Personal communication.

Cameron, H.L. (1965). The Shifting Sands of Sable Island. The Geographical Review, American Geographical Society. 55:463-476.

Canada-Nova Scotia Offshore Petroleum Board. (1988). Canada-Nova Scotia Offshore Petroleum Resources Accord Implementation Act, (S.C. 1988 c. 28), s pecifically Section 140.1 and Schedule II. Dept. of Justice website accessed 27 May 2015.

Craymer,M.(2015). Geodetic Survey, Natural Resources Canada, Ottawa. Personal communication.

Fillmore, S. \& Sandilands, R.W. (1983). The Chartmakers. NC Press Ltd., Toronto, ON.

Government of Canada. (1978a). Sable Island Regulations, Consolidated Regulations of Canada (CRC), 1978, c. 1465. Dept. of Justice website accessed 27 May 2015.

Government of Canada. (1978b). Territorial Sea Geographical Coordinates Order, Consolidated Regulations of Canada (CRC), 1978, c. 1550. Dept. of Justice website accessed 27 May 2015.

Government of Canada. (2001). Canada Shipping Act 2001 (S.C. 2001, c. 26). Dept. of Justice website accessed 27 May 2015.

Government of Canada. (nd). (1912-91) Notices to Mariners (issued weekly), Canadian Coast Guard, Ottawa.

Government of Canada. (nd). (1912-91) List of Lights Buoys and Fog Signals (issued annually), Canadian Coast Guard, Ottawa.

Government of the United Kingdom. (1965). Admiralty Manual of Hydrographic Surveying, Vol. 1 (1965). Hydrographer of the [Royal] Navy, London.

Kerr, A.J. (1983). Surveying the Sands off Sable. Lighthouse 27:22-24.

McKenzie, R. (ed.). (1984). The St. Lawrence Survey Journals of Captain Henry Wolsey Bayfield, 1829-1853, Vol. I. The Champlain Society, Toronto, ON.

McKenzie, R. (ed.). (1986). The St. Lawrence Survey Journals of Captain Henry Wolsey Bayfield, 1829-1853, Vol. II. The Champlain Society, Toronto, ON. 
Statutes of Canada. (2000). Canada National Parks Act, Statutes of Canada (S.C.) 2000, c. 32, specifically Schedule 2. Dept. of Justice website, accessed 27 May 2015.

Stephens, D.E. (1973). Lighthouses of Nova Scotia. Lancelot Press, Windsor, NS.

Thomson, M.M. (1978). The Beginning of the Long Dash: A History of Timekeeping in Canada. University of Toronto Press, Toronto, ON.

United Nations Convention on the Law of the Sea (UNCLOS). (1983) United Nations, New York, NY.

Witney, D. (1975). The Lighthouse. McClelland \& Stewart, Toronto, ON.

\section{RESEARCHED DOCUMENTS}

\section{Maps and Charts of Sable Island}

Canadian Hydrographic Service. (1952). CHS chart 4490, Atlantic Coast, Gulf \& River St. Lawrence, published 1952, 1:1,293,000.

Canadian Hydrographic Service. (1984). CHS chart L/C 4098, Sable Island, published 1984, 1:100,000.

DesBarres, J.F.W. (1777). Isle of Sable,1777 circa 1;120,000 On file at Public Archives of Nova Scotia (Halifax) and Public Archives of Canada (Ottawa). Low-grade scan can be downloaded from Boston Public Library website: http://maps.bpl.org/id/15167 (accessed 7 March 2016) or from National Maritime Museum (Greenwich) website http://collections.rmg. co.uk/collections/objects/542281.html (accessed 7 March 2016).

Government of Canada. (1899). British Admiralty chart 1651, Nova Scotia, Prince Edward I. and part of New Brunswick, published 1943, 1:725,000, Inset of Sable Island, 1:217,000. (1899 Cdn. Govt. Survey). [Public Archives of Canada, NMC 118339].

Government of Canada. (1899).British Admiralty chart 1651, Nova Scotia, Prince Edward I. and part of New Brunswick, published 1941, 1:725,000, Inset of Sable Island, 1:217,000,(1899 Cdn Govt Survey),[Public Archives of Canada, NMC 118341].

Government of Canada. (1947). British Admiralty chart 1651, Nova Scotia, Prince Edward Island and part of New Brunswick, published 1962, 1:725,000, Inset of Sable Island, 1:217,000, (1947 Cdn Govt Survey),[Public Archives of Canada, NMC 118340].

Government of Canada. (1967). National Topographic Map 10N/16 (et al.), Sable Island, published 1967, 1:50,000.

Government of the United Kingdom. (1851a). British Admiralty Fairsheet L7820, Survey of Sable Island and Surrounding Waters, Capt. HW Bayfield, RN, 1851, 1:73,400 (approx), [British Admiralty].

Government of the United Kingdom. (1851b). British Admiralty Rough Sheet D9148, Survey of Sable Island and Surrounding Waters, Capt. HW Bayfield, RN, 1851, 1:72,900 (approx). [British Admiralty].

Government of the United Kingdom. (1853). British Admiralty chart 2171, Sable Island, published 1853, 1:217,000 (approx), Inset of Sable Island, 
1:71,600 (approx), (1851 survey by Capt. HW Bayfield, RN), [Public Archives of Canada, NMC 103684].

Government of the United Kingdom.(1893). British Admiralty chart 1651,

Nova Scotia, Prince Edward I. and part of New Brunswick, published 1893, (no inset of Sable Island), [Public Archives of Canada, NMC 111380].

Government of the United Kingdom.(1897). British Admiralty chart 1651, Nova Scotia, Prince Edward Island and part of New Brunswick, published 1897, (no inset of Sable Island), [British Admiralty].

Government of the United Kingdom. (1899). British Admiralty Fairsheet B8922, Survey plan of Sable Island, LtCol WmP Anderson, CE, 1899, 1:36,090, [British Admiralty].

Government of the United Kingdom.(1904). British Admiralty chart 2171, Sable Island, published 1904, 1:221,000 (approx), Inset of Sable Island, 1:72,800 (approx), (1899 survey by WmPAnderson, Chief Engineer, Dept Marine \& Fisheries, Canada), [Public Archives of Canada, NMC 103683]. Hydrographic \& Map Service of Canada. (1947). Map S-117, Sable Island, published 1947, 1:63,360.

Stilwell, W.H. (1947). (Geodetic Survey of Canada), [Plan of survey of West Light on] Sable Island, April 1947, 1:4800.

\section{Charts of Quebec City and Halifax:}

Canadian Hydrographic Service. (1990a). CHS chart 4202, Halifax Harbour - Point Pleasant to/à Bedford Basin, published 1990, 1:10,000.

Canadian Hydrographic Service. (1990b). CHS 1316, Port de Québec, published 1990, 1:15,000.

Government of the United Kingdom. (1829). British Admiralty chart 319, Plan of the Harbour and Basin of Quebec, published 1829, 1:24,300 (approx).

Government of the United Kingdom. (1854). British Admiralty chart 2320, Halifax Harbour, published 1854, [Public Archives of Canada, NMC 78628].

Government of the United Kingdom. (1869). British Admiralty chart 2320, Halifax Harbour, published 1869, [Public Archives of Canada, NMC 111384]. 


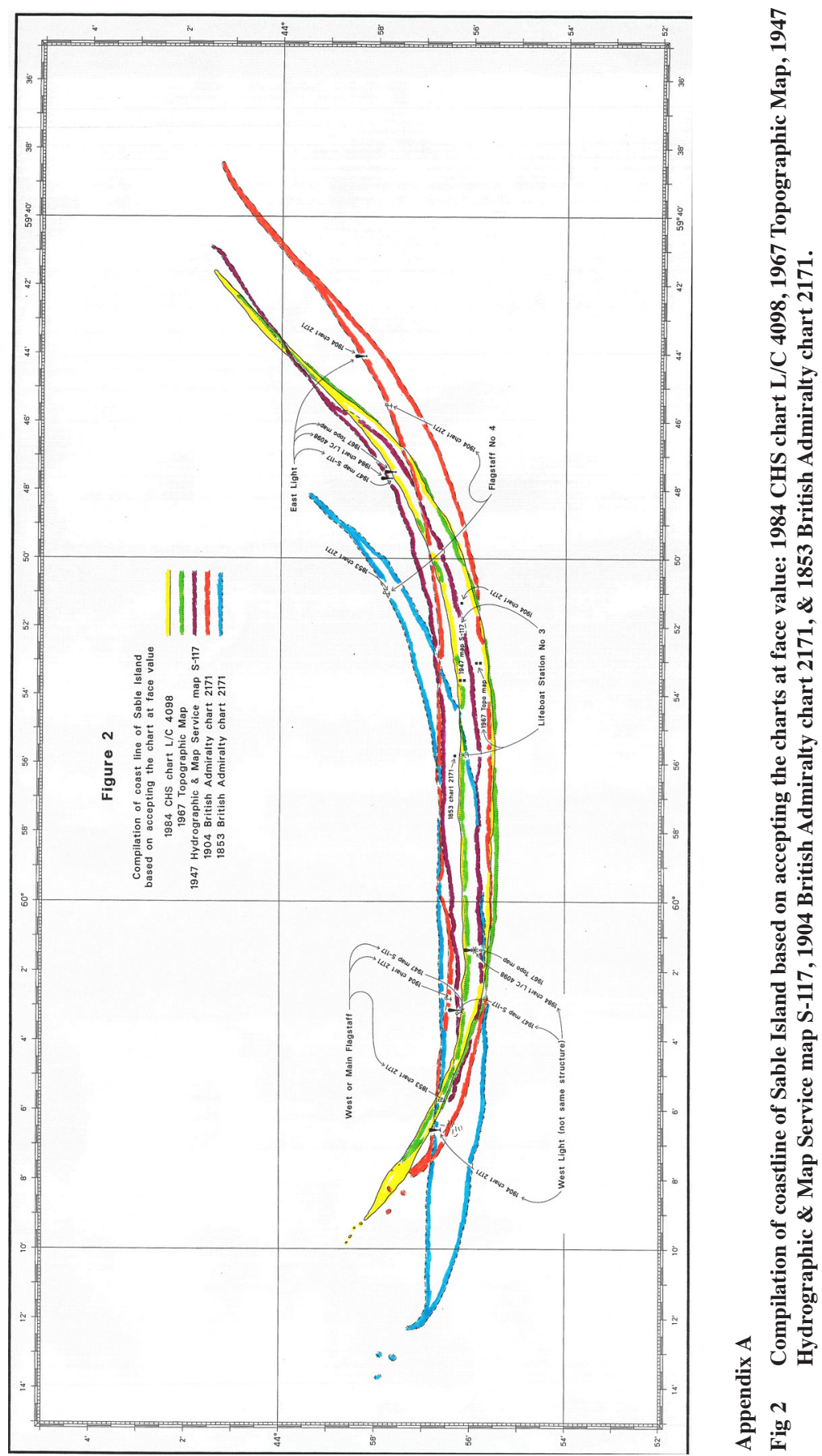




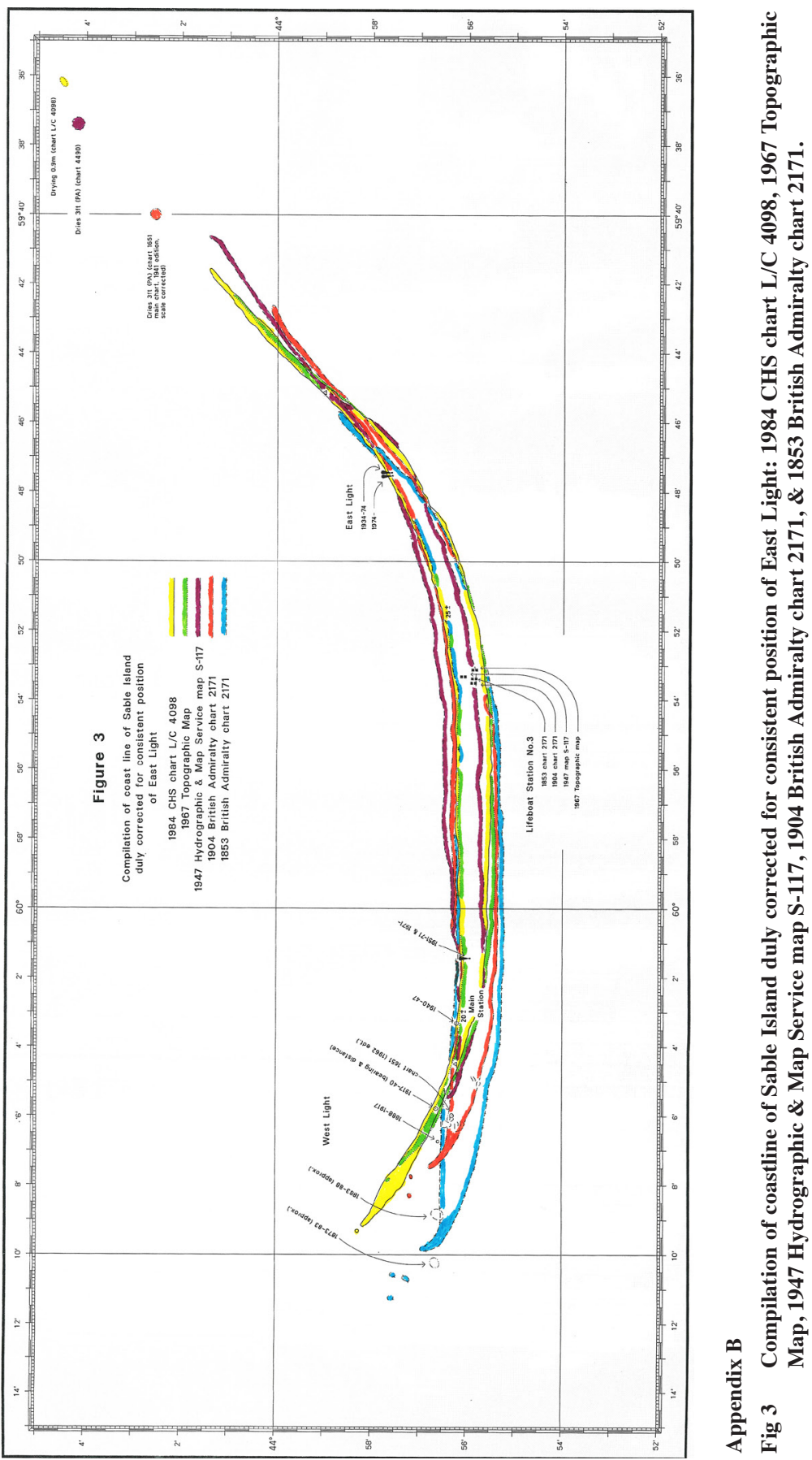

